\title{
KAJIAN FAKTOR YANG DAPAT MENINGKATKAN PARTISIPASI MASYARAKAT DALAM PROGRAM DESA MAJU INHIL JAYA (DMIJ)
}

\author{
Rezky Kinanda ${ }^{1}$, Roberta Zulfhi Surya ${ }^{2}$ \\ ${ }^{1}$ Program Studi Teknik Sipil, Fakultas Teknik dan Ilmu Komputer, Universitas Islam Indragiri \\ ${ }^{2}$ Program Studi Teknik Industri, Fakultas Teknik dan Ilmu Komputer, Universitas Islam Indragiri \\ Email: kinandaofficial@gmail.com (korespondensi)
}

\begin{abstract}
The DMIJ program is a noble program from the Indragiri Hilir Regency Government to advance the villages in this district. The community is a welfare target as well as an element driving the success of the DMIJ program. This program is one of the government's flagship programs to advance villages in Inhil Regency. There are not many scientific studies have specifically addressed this program.

There are actors who must work together in order to achieve the goal of this program. In addition, the factors that influence the success of this program must be maximized by these actors and implemented in a sustainable manner.

This journal explained what matters should be the District Government in order to maximize the activities that will be carried out at the Integrated DMIJ Plus. This journal discussed how important the role of the community is in the DMIJ program and what factors can influence community participation. This journal is expected to become a consideration for the government to win the hearts of the people so that they are willing to work together to make the DMIJ program a success..
\end{abstract}

Keywords: Society, Participation, DMIJ, Competent Officials, Technical, Sociology, Psychology

\section{Abstrak}

Program DMIJ adalah program mulia dari Pemerintah Kabupaten Indragiri Hilir guna memajukan desa-desa di kabuoaten ini. Masyarakat adalah target pensejahteraan sekaligus elemen penggerak guna mencapai kesuksesan program DMIJ. Program ini menjadi salah satu unggulan pemerintah untuk memajukan desa-desa di Kabupaten Inhil. Belum banyak kajian-kajian ilmiah yang membahas khusus program ini.

Terdapat aktor-aktor yang harus berkerjasama guna mendapatkan keberhasilan dalam program ini. Ditambah lagi faktor-faktor yang mempengaruhi keberhasilan program ini harus dimaksimalkan oleh aktor-aktor tersebut dan dijalankan dengan berkesinambungan.

Jurnal ini menjelaskan hal-hal apa saja yang harus dilakukan oleh Pemerintah Kabupaten agar bisa memaksimalkan kegiatan-kagiatan yang akan dilakukan dalam DMIJ plus Terintegrasi. Jurnal ini akan membahas seberapa penting peran masyarakat dalam program DMIJ serta faktor apa saja yang dapat mempengaruhi partisipasi masyarakat. Diharapkan jurnal ini bisa menjadi pertimbangan pemerintah untuk meraih hati masyarakat agar mau berjuang bersama mensukseskan program DMIJ ini.

Kata kunci: Masyarakat, Partisipasi, DMIJ, Pejabat Berwenang, Teknis, Sosiologi, Psikkologi

\section{PENDAHULUAN}

Peran penting perdesaan sebagai elemen vital dari sebuah wilayah adalah hal yang harus menjadi perhatian Pemerintah Pusat hingga Pemerintah Daerah. Perdesaan tidak boleh dianggap sebagai daerah yang secara mutlak sebagai daerah yang statusnya rendah. Diketahui bahwa wilayah perdesaan memiliki banyak fungsi, diantaranya adalah sebagai produsen kebutuhan perkotaan, sebagai mitra pembangunan perkotaan, sebagai bentuk pemerintahan terkecil di Negara Indonesia.

Perdesaan seringkali dianggap sebagai wilayah tertinggal dikarenakan dari segi pembangunan fisik, wilayah perdesaan tidak memiliki bangunan-bangunan besar, pusat perbelanjaan modern, fasilitas rekreasi 
modern, dan pembangunan-pembangunan fisik layaknya perkotaan. Namun, Perdesaan juga memiliki potensi yang sangat luar biasa yang seharusnya bisa dimanfaatkan dengan baik.

Dari segi potensi fisik, perdesaan memiliki potensi tanah, air, iklim dan cuaca, flora dan fauna yang tidak dimiliki perkotaan. Berbagai pemanfaatan bisa dikembangkan pada potensi ini, seperti perkebunan, pertanian, perternakan, wisata alam, dll. Sedangkan dari segi potensi non fisik perdesaan memiliki masyarakat desa, lembaga sosial desa, dan aparatur desa yang apabila diberikan edukasi yang baik akan memiliki potensi sebagai SDM yang mampu mengembangkan dan mengemas potensi fisik perdesaan menjadi nilai yang sangat berharga.

Hal ini mungkin disadari dengan benar oleh Pemerintah Kabupaten Indragiri Hilir. Beragam potensi dimiliki desa-desa di Kabupaten Inhil. Luas tanaman kelapa di Inhil lebih kurang mencapai 432 ribu hektar yang dengan sektor kelapa ini berbagai produk bisa dihasilkan seperti Kopra, Minyak kelapa, Kelapa parut kering, Arang tempurung kelapa, Serat sabut kelapa, Gula kelapa, bahkan belum lama ini telah dihasilkan produk makanan seperti jelly dan keripik.

Program yang menjadi andalan Pemerintah Inhil dalam usaha memajukan perdesaan di Inhi adalah Program Desa Maju Inhil Jaya (DMIJ). Program DMIJ adalah program pemerintah kabupaten melalui pendekatan pemberdayaan dengan mengefektifkan fungsi pemerintah desa, kelembagaan desa untuk merencanakan, melaksanakan, melestarikan dan pengawasan pembangunan secara partisipatif. Pemerintah daerah kabupaten indragiri hilir pada tahun 2014 telah meluncurkan program DMIJ dan sebagai dasar hukum utama dalam pelaksanaan program tersebut telah diterbitkan peraturan daerah kabupaten indragiri hilir nomor 5 tahun 2014 tentang rencana pembangunan jangka menengah daerah tahun 2014-2018.

Dengan tujuan mulia Pemerintah Inhil, program ini bukan berarti pasti akan terlaksana dengan baik. Dalam beberapa penelitian ilmiah dapat dikatakan Program DMIJ ini mengalami berbagai kendala dan belum terlaksana secara optimal. Sebagai contoh dalam penelitian berjudul Evaluasi Pelaksanaan Program Desa Maju Inhil Jaya (Dmij) Desa Nusantara Jaya Kecamatan Keritang Kabupaten Indragiri Hilir, penulis mangambil kesimpulan bahwa pelaksanaan program ini masih belum optimal karena masih terdapat 17 kegiatan yang tidak terlaksana dengan optimal.

Hal ini dikarenakan pelaksanaan menghadapi kendala seperti kurang efektifnya pelaksanaan program DMIJ dikarenakan oleh rendahnya kemampuan pelaksana dalam memenuhi ketentuan implementasi program yang tepat sasaran , tepat jumlah dan tepat mutu, kurang efisiennya pelaksanaan program DMIJ, kurang tercukupinya pelaksanaan program DMIJ yang sesuai dengan kebutuhan masyarakat desa disebabkan oleh keterbatasan SDM yang berkualitas, kurang meratanya pelaksanaan program DMIJ dikarenakan kurang mampunya pelaksana dalam menyusun sendiri rencana pembiayaan pembangunan infrastruktur yang akan dilakukan, kurang responya pelaksana program DMIJ, kurang tepat pelaksanaan Program DMIJ disebabkan oleh ketidakmampuan implementor dengan merealisasikan infrastruktur desa yang sesuai dengan kebutuhan masyarakat.

Semua permasalahan di atas mengakibatkan rendahnya partisipasi dan keinginan masyarakat desa untuk memanfaatkan dan memelihara infrastruktur yang sudah disediakan. Padahal masyarakat memiliki peran vital dalam program ini.

Tentu program DMIJ tidak bisa dikatakan gagal dikarenakan banyak prestasi yang sudah diraih Pembangunan sarana dan prasarana seperti jembatan, jalan, jerambah dan sarana air bersih, program magrib mengaji, bantuan insentif guru PAUD serta pembinaan kader pos yandu, dll. Namun, Program ini juga tidak bisa dikatakan berhasil secara mutlak seperti yang sudah kita bahas sebelumnya bahwa terjadi banyak permasalahan di lapangan.

Jurnal ini bertujuan untuk membantu Program DMIJ yang sejak tahun 2019 ditingkatkan programnya menjadi Program DMIJ plus Terintegrasi oleh Pemerintah Inhil. Bantuan jurnal ini bersifat pemaparan peran penting masyarakat yang harus digali dan dan aspek apa yang harus dikuatkan guna merangsang partisipasi masyarakat agar memiliki keinginan lebih dalam untuk memajukan program ini. Pemaparan ini adalah hasil kejian teori mendalam dari berbagai ahli dalam beberapa buku ilmiah, jurnal ilmiah, serat dokumen-dokumen kajian ilmiah lainnya.

\section{Masyarakat sebagai Elemen Utama}

People power adalah suatu slogan yang telah populer di kalangan orang awam. Pergerakan masyarakat mampu merubah suatu kebijakan bahkan mampu untuk menciptakan sejarah. Sebuah hal yang di masa kini telah menjadi teramat sering digaungkan sebagai alat menyampaikan pendapat.

Partisipasi menurut Huneryear dan Heoman dalam Siti Irene Astuti D. (2009) adalah sebagai keterlibatan mental dan emosional dalam situasi kelompok yang mendorongnya memberi sumbangan terhadap tujuan kelompok serta membagi 
tanggungjawab bersama mereka. Dari pendapatan ini bisa ditarik poin penting bahwa masyarakat adalah elemen penting yang menjadi penggerak sebuah program di daerah mereka.

Pendefisian tentang partisipasi juga diterangkan oleh Fasli Djalal dan Dedi Supriadi (2001) di mana partisipasi dapat bermakna bahwa pembuat keputusan menyarankan kelompok atau masyarakat ikut terlibat dalam bentuk penyampaian saran dan pendapat, barang, keterampilan, bahan dan jasa. Partisipasi dapat juga berarti bahwa kelompok mengenal masalah mereka sendiri, mengkaji pilihan mereka, membuat keputusan, dan memecahkan masalahnya. Pendapat ini memperkuat pandangan bahwa masyarakat memiliki kekuatan yang besar untuk mempengaruhi jalannya program atau kebijakan yang diambil.

Selain itu Mikkelsen (1999) turut membagikan makna partisipasi dimana beliau membagi partisipasi menjadi 6 (enam) pengertian, yaitu:

1. Partisipasi adalah persembahan sukarela dari masyarakat kepada kebijakan/program tanpa terlibat dalam pengambilan keputusan

2. Partisipasi adalah usaha untuk membuat pihak masyarakat berhasrat untuk meningkatkan kemauan menerima dan kemampuan untuk terlibat dalam program-program pembangunan

3. Partisipasi adalah aktifitas sukarela oleh masyarakat dalam usaha membuat perubahan yang ditentukan oleh masyarakat sendiri

4. Partisipasi adalah suatu proses yang aktif yang bermakna orang atau kelompok yang terlibat mengambil inisiatif dan menggunakan kebebasannya untuk melakukan hal itu

5. Partisipasi adalah penguatan diskusi antara masyarakat lokal dengan pejabat yang melakukan persiapan, pelaksanaan, monitoring proyek. Hal ini dilakukan untuk mendapatkan informasi tentang konteks lokal, dan dampak-dampak sosial 6. Partisipasi adalah keterlibatan masyarakat dalam pembangunan diri, kehidupan, dan lingkungan mereka.

Dari beberapa pendapat para ahli di atas, penulis menyimpulkan beberapa hal penting. Pertama adalah bahwa kekuatan partisipasi masyarakat adalah salah satu tiang utama yang harus diperkuat untuk membangun sebuah program kebijakan. Masyarakat juga bisa menjadi "alat" yang bisa digunakan untuk mencapai tujuan baik dari program yang sedang dikembangkan. Dan yang kedua adalah bahwa partisipasi setiap kelompok masyarakat di tiap-tiap daerah akan menunjukan reaksi yang berbeda-beda pula.
Kelompok masyarakat di suatu daerah tidak seperti kertas putih kosong dimana pejabat pengambil kebijakan bisa dengan mudah melukis apapun yang diinginkan. Kelompok masyarakat bagaikan sebuah kertas yang telah terlukis sebelumnya, terlukis oleh waktu, budaya, gaya hidup, kondisi alam, dan lain-lain. Sehingga jika pemerintah ingin melukis di wilayah kelompok masyarakat tertentu, para pejabat harus mempersiapkan alat lukis serta penghapus yang cukup kuat dan mampu mewarnai masyarakat sehingga masyarakat dengan suka rela diwarnai demi kemajuan bersama.

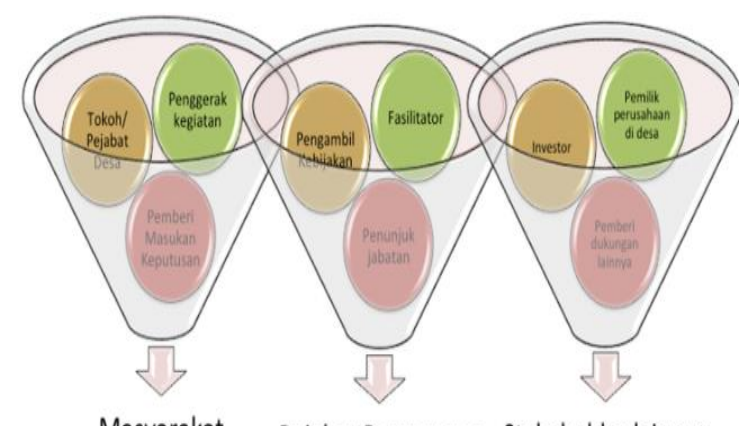

Masyarakat Pejabat Berwenang Stakeholder lainnya

\section{Gambar 1. Gambaran Keterlibatan Aktor}

Terdapat banyak aktor yang terlibat dalam DMIJ dan program-program yang melibatkan partisipasi masyarakat. Yang pertama tentu adalah masyarakat seperti yang telah kita bahas sebelumnya bahwa masyarakat adalah elemen kuat dalam program kebijakan pemerintah. Kedua tentu adalah pejabat berwenang itu sendiri sebagai pejabat legal yang melegalkan kebijakan, program, dll. Dan yang ketiga adalah aktor pendukung lainnya atau stakeholder lainnya.

\section{Kajian Faktor yang Mempengaruhi Partisipasi Masyarakat}

Kita telah memahami bahwa peran masyarakat memiliki kekuatan yang sangat besar. pertanyaan selanjutnya adalah apa saja faktor yang dapat mempengaruhi partisipasi masyarakat guna menghasilkan peran masyarakat yang diharapkan ?

Bekerja sama dengan masyarakat bukanlah hal yang mudah untuk dilakukan. Perjuangan pelaksanakan kebijakan akan menemui banyak permasalahan. Permasalahan bisa saja terdapat di pihak pejabat pembuat kebijakan, atau permaslahan terdapat di pihak masyarakat, atau bahkan terdapat di stakeholder lain yang terlibat yang turut mempengaruhi jalannya proses pelaksanaan program atau kebijakan. Permasalahan-permasalahan yang ditemui tentu merupakan hal yang 
dapat mempengaruhi proses partisipasi masyarakat. Faktor-faktor inilah yang harus mendapat perhatian lebih banyak pejabat pembuat kebijakan.

Menurut Slamet (dalam sunarti, 2003), tingkah laku individu berhubungan erat atau ditentukan oleh ciri-ciri sosiologis seperti umur, jenis kelamin, pendidikan, pekerjaan, penghasilan, lamanya menjadi anggota masyarakat. Pendapat slamet dilengkapi oleh perkataan Mohtar dan Chollin (2011) bahwa di samping pendidikan, perbedaan jenis kelamin dan status sosial, faktor ekonomis juga mempengaruhi keaktifan seseorang dalam berpartisipasi. Dalam pendapat ini di jelaskan bahwa tingkah laku individu masyarakat secara psikologis dipengaruhi oleh faktor sosiologis. Dalam artian bahwa psikologis individu masyarakat tentang berminat atau tidak berminat dia untuk berpartisipasi di program tertentu sangat dipengaruhi faktor sosiologis yang dijelaskan pada pendapat diatas.

Pendapat lain yang juga menguatkan pendapat Slamet adalah pendapat Rush dan Althoff (2005), mereka berpendapat bahwa karakteristik sosial seseorang seperti penghasilan, pendidikan, kelompok ras atau etnis, usia, jenis kelamin, lamanya tinggal dan agamanya, baik ia hidup di daerah perdesaan atau di kota, maupun ia termasuk dalam organisasi sukarela tertentu dan sebagainya, semua mempengaruhi partisipasi politik individu masyarakat. Penjelasan lebih rinci dijabarkan oleh Plumer (dalam Yulianti,2012:10), bahwa faktor yang mempengaruhi masyarakat untuk mengikuti proses partisipasi adalah:

a. Pengetahuan dan keahlian. Landasan pengetahuan yang dipunyai masyarakat akan mempengaruhi seluruh lingkungan dari masyarakat tersebut. Keadaan ini menjadi penentu bagaimana pemahaman masyarakat terhadap tahap-tahap dan bentuk dari partisipasi yang ada

b. Pekerjaan masyarakat. Jenis atau tingkatan pekerjaaan masyarakat akan menentukan apakah mereka akan meluangkan waktunya untuk berpartisipasi pada suatu proyek tertentu atau justru tidak sama sekali Seringkali alasan yang mendasar pada masyarakat adalah adanya pertentangan antara komitmen terhadap pekerjaan dengan keinginan untuk berpartisipasi.

c. Tingkat pendidikan dan buta huruf. Faktor ini berpengaruh sangat kuat bagi keinginan dan kemampuan masyarakat untuk berpartisipasi serta untuk memahami dan melaksanakan tingkatan dan bentuk partisipasi yang ada.

d. Jenis kelamin. Sebagian masyarakat masih menganggap faktor inilah yang dapat mempengaruhi keinginan dan kemampuan masyarakat untuk berpartisipasi. Anggapan yang ada adalah bahwa laki-laki dan perempuan akan mempunyai persepsi dan pandangan berbeda terhadap suatu pokok permasalahan

e. Kepercayaan terhadap budaya tertentu. heterogenitas ataupun homogenitas masyarakat di wilayah program kebijakan akan sangat berpengaruh terhadap budaya dan kepercayaan yang mereka anut. Seringkali kepercayaan yang dianut dapat bertentangan dengan kebijakan program yang ada. Hal ini tentu akan berbeda manakala di wilayah tersebut memiliki heterogenitas yang besar dan masyarakat tidak terlalu terikat dengan suatu kepercayaan tertentu.

Penulis juga telah menggali lebih dalam tentang faktor yang mempengaruhi partisipasi masyarakat yang belum disebutkan oleh para ahli sebelumnya. Holil (1980: 10) menekankan faktor lingkungan atau di luar diri dari masyarakat yang dapat mempengaruhi partisipasi masyarakat, yaitu:

a. Komunikasi antara sesama warga masyarakat, antara warga masyarakat dengan pimpinannya serta antara sistem sosial di dalam masyarakat dengan sistem di luarnya;

b. Iklim sosial, ekonomi, politik dan budaya, baik dalam kehidupan keluarga, pergaulan, permainan, sekolah maupun masyarakat dan bangsa yang mendorong tumbuh dan berkembangnya partisipasi masyarakat

c. Kesempatan untuk berpartisipasi. Keadaan lingkungan serta proses dan struktur sosial, sistem nilai dan normanorma yang memungkinkan dan mendorong terjadinya partisipasi sosial

d. Kebebasan untuk berprakarsa dan berkreasi. Lingkungan di dalam keluarga, masyarakat atau lingkungan politik, sosial, budaya yang memungkinkan dan mendorong timbul dan berkembangnya prakarsa, gagasan, perseorangan atau kelompok

Dari beragam pendapat para ahli yang penulis ambil pendapatnya, penulis mengambil kesimpulan bahwa para ahli yang meneliti faktor-faktor yang mempengaruhi partisipasi masyarakat dalam program/kebijakan tidak secara spesifik membedakan antara faktor teknis dan nonteknis. Dalam artian faktor-faktor tersebut pada umumnya dikelompokan dalam satu wadah.

Di tahap ini penulis mengambil kesimpulan dan membuat kerangka berpikir sebagai berikut: 


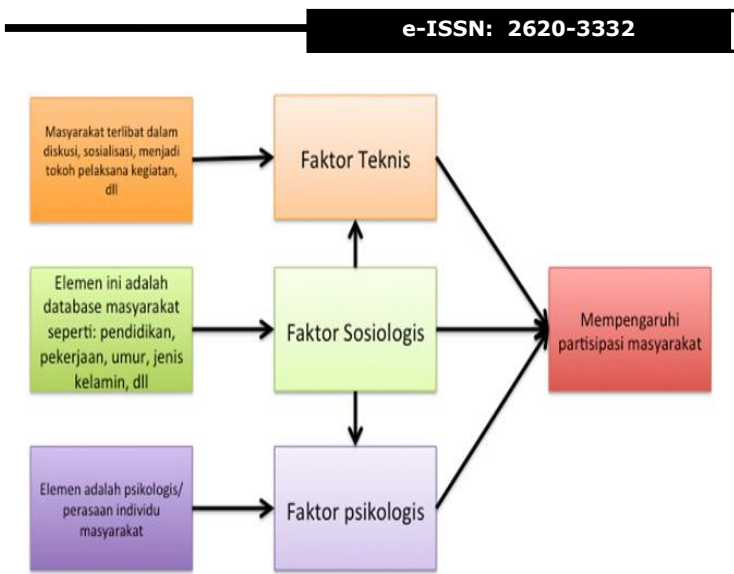

Gambar 2 Kerangka Alur Faktor Pengaruh Partisipasi Masyarakat

Dari kerangka di atas penulis menjelaskan bahwa kondisi sosiologis masyarakat seperti pendidikan, pekerjaan, umum, pendapatan, dll merupakan sumber faktor sosiologis yang mampu mempengaruhi minat dan intensitas masyarakat. Kemudian faktor teknis seperti jabatan kepala desa, RT, RW, dan faktor jabatan resmi lainnya yang ditunjuk oleh pemerintah dapat membuat masyarakat tertentu harus berpartisipasi dikarenakan tuntutan jabatan. Di dalamnya juga termasuk program kegiatan resmi yang dilaksanakan oleh pemerintah/pembuat kebijakan seperti rapat resmi, diskusi dan sosialisasi resmi dari pemerintah/pembuat kebijakan.

Kemudian terdapat faktor psikologis individu yang sangat kuat mempengaruhi tindakan individu masyarakat. Faktor psikologis ini juga dipengaruhi oleh faktor teknis atau sosiologis. Namun pertanyaan selanjutnya elemen apa saja yang mengisi faktor psikologis ini ?

\section{Faktor Psikologis}

Penulis telah menjelaskan pada penjelasan sebelumnya mengenai faktorfaktor yang mempengaruhi partisipasi masyarakat. Faktor teknis dan sosiologis adalah faktor yang sangat penting untuk meningkatkan peran masyarakat. Faktor ini telah dijelaskan oleh penulis sebelumnya.

Selanjutnya penulis juga memberikan perhatian yang tinggi terhadap sebuah faktor yang menekankan kepada psikologi masyarakat. Faktor psikologis yang dimagsud penulis pada kajian ini bermain dalam area diri perasaan individu masyarakat yang tentunya bersifat psikologis.

Hal ini lah yang disampaikan oleh Holil (1980). Beliau menerangkan lebih dalam tentang faktor-faktor dasar partisipasi sosial yang juga dapat mempengaruhi partisipasi masyarakat. Faktor-faktor tersebut adalah:

a. Kepercayaan diri masyarakat.

b. Solidaritas dan integritas sosial masyarakat:

c. Tanggungjawab sosial dan komitmen masyarakat;

d. Kemauan dan kemampuan untuk mengubah atau memperbaiki keadaan dan membangun atas kekuatan sendiri;

e. Prakarsa masyarakat atau prakarsa perseorangan yang diterima dan diakui sebagai/menjadi milik masyarakat;

f. Kepentingan umum murni, setidaktidaknya umum dalam lingkungan masyarakat yang bersangkutan, dalam pengertian bukan kepentingan umum yang semu karena pencampuran kepentingan perseorangan atau sebagian kecil dari masyarakat;

g. Organisasi, keputusan rasional dan efisiensi usaha;

h. Musyawarah untuk mufakat dalam pengambilan keputusan;

i. Kepekaan dan daya tanggap masyarakat terhadap masalah, kebutuhankebutuhan dan kepentingan-kepentingan umum masyarakat.

Dari penjelasan di atas dapat dilihat bahwa beliau mencantumkan 5 dari 9 faktor adalah faktor yang bersifat psikologis individu masyarakat. Faktor tersebut adalah kepercayaan diri masyarakat, rasa solidaritas, tanggung jawab, kemauan dan kemampuan, serta daya tanggap individu masyarakat. Kesemuanya ini adalah berasal dari jiwa individu masyarakat.

Pandangan ini diperkuat juga oleh para ahli diantaranya adalah Slamet (2003) yang menyatakan bahwa tumbuh dan berkembangnya partisipasi masyarakat dalam pembangunan, sangat ditentukan oleh tiga unsur pokok yaitu:

a. Adanya kesempatan yang di berikan kepada masyarakat untuk berpartisipasi.

b. Adanya kemampuan masyarakat untuk berpartsisipasi

c. Adanya kemauan masyarakat untuk berpartisipasi

Satu dari tiga unsur pokok ini adalah unsur yang sifatnya berada di dalam perasaan individu masyarakat yaitu kemauan. Unsur yang pertama yaitu berupa kesempatan yang di berikan kepada masyarakat untuk berpartisipasi bisa diakomodir oleh foktor teknis dimana pejabat berwenang bisa memfasilitasi masyarakat agar memiliki ranah, media, dan kesempatan untuk berpartisipasi. Unsur yang kedua bisa ditentukan oleh faktor sosiologis dimana pendidikan, pengetahuan, umur, pengalaman, dan lain sebagainya mempengaruhi kemampuan masyarakat untuk berpartisipasi. Dan unsur yang terakhir harus ditentukan oleh sebagaimana pejabat berwenang mampu mensugesti psikologis individu masyarakat agar memiliki kemauan untuk berpartisipasi. 
Penulis memperkuat eksistensi faktor psikologis sebagai faktor yang mempengaruhi partisipasi masyarakat melalui penejelasan Ife dan Tesoriero (2008) bahwa hal-hal yang mendorong dan mendukung orang berpartisipasi adalah sebagai berikut:

a. Orang berpartisipasi apabila mereka merasa bahwa isu atau aktivitas tersebut penting.

b. Orang merasa bahwa aksi mereka akan membuat perubahan;

c. Bahwa berbagai bentuk partisipasi harus diakui dan dihargai;

d. Bahwa orang harus bisa berpartisipasi, dan didukung dalam partisipasinya;

e. Bahwa struktur dan proses tidak boleh mengucilkan

Hampir keseluruhan faktor yang dijelaskan oleh Ife dan Tesoriero adalah faktor yang sangat lekat dengan psikologis individu masyarakat. Pendapat ini mempertajam dan mengkokohkan eksistensi faktor psikologis sebagai faktor yang sangat kuat untuk meningkatkan partisipasi masyarakat.

Berdasarkan kajian teori sejauh ini kita melihat bahwa setidaknya ada 6 elemen di dalam faktor psikologis. Mereka adalah rasa ingin atau kemauan masyarakat untuk terlibat, kepercayaan diri, merasa dibutuhkan untuk turut andil, merasa harus terlibat, merasa tidak dikucilkan, dan merasa dihargai. Sejauh kajian teori yang penulis lakukan 6 elemen psikologis inilah yang harus dijaga dan diperkuat oleh pejabat berwenang melalui faktor teknis yang dilaksanakan.

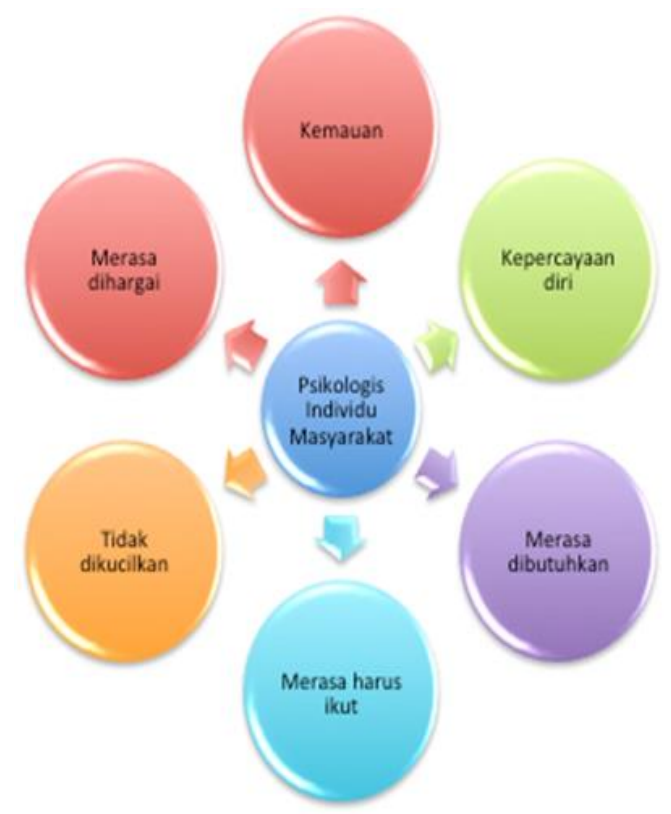

Gambar 3 Diagram Psikkologis individu masyarakat untuk ikut berpartisipasi

\section{Mind Mapping faktor untuk program DMIJ}

Dalam perjalannya kajian ini secara perlahan memperkuat teori-teori dari para ahli, hal ini juga memperkuat dan menstrukturkan mind mapping yang diharapkan dapat membantu usaha pejabat berwenang untuk meningkatkan partisipasi masyarakat. Berikut mind mapping setelah menelaah berbagai pendapat ahli dan sudah dijabarkan sebelumnya secara terperinci.

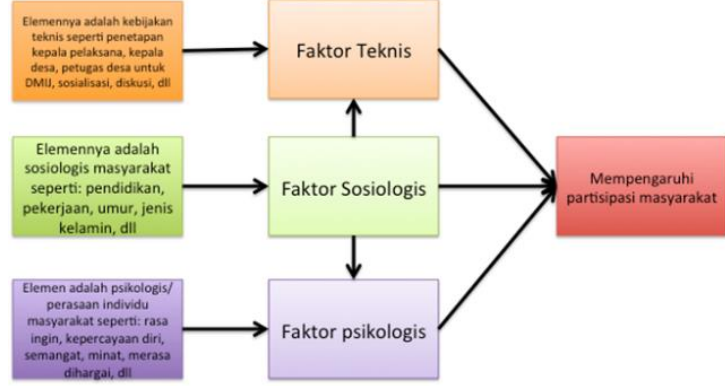

Gambar 4 Kerangka berpikir faktor-faktor Partisipasi masyarakat

Kerangka ini menjelaskan konsep mind mapping yang dapat digunakan sebagai bahan acuan guna meningkatkan performa partisipasi masyarakat dalam program DMIJ. Terdapat 3 faktor yang dapat mempengaruhi partisipasi masyarakat baik kearah positif maupun kearah negative. Tergantung bagaimana penanganan pejabat pengambil kebijakan. Tiga faktor itu adalah faktor sosiologis, faktor teknis, dan faktor psikologis.

Faktor pertama yang memiliki peran sentral yaitu faktor sosiologis. Faktor ini memiliki dua keistimewaan. Keistimewaan pertama faktor sosiologis ini adalah faktor yang bersumber dari masyarakat yang terdata dan kasat mata bisa dideteksi oleh pejabat pengambil kebijakan. Faktor sosiologis ini seperti data pendidikan, pekerjaan, umur, jeni kelamin, kehidupan budaya, dll. Sehingga dari faktor sosiologis inilah pejabat bisa membuat tatanan teknis. Tatanan teknis ini adalah teknis program dijalankan seperti pemilihan dan penunjukan masyarakat pelaksana, diskusi, sosialisasi, dan proses teknis lainnya. Tatanan teknis inilah yang disebut faktor teknis.

Keistimewaan kedua adalah faktor sosiologis ini sangat mempengaruhi kondisi psikologis setiap individu masyarakat. Bagaimana kondisi pendidikan, pekerjaan, umur, dan kondisi masyarakat lainnya dapat menjadi sebagian penentu ada tidaknya hasrat masyarakat untuk turut berpartisipasi.

Setiap faktor memiliki keistimewaan masing-masing. Faktor teknis dengan keformalitasannya, kebijakan legalnya, serta aksi nyata kegiatannya seperti diskusi dan 
sosialisasi dapat memberikan "dorongan paksaan" kepada masyarakat untuk berpartisipasi. Faktor sosiologis yang dapat menggambarkan peta kondisi masyarakat setempat dengan cukup baik. Dimana kondisi masyarakat sebuah desa yang mayoritas petani tentu akan berbeda dengan masyarakat yang mayoritas pedagang dari segini pendekatannya. Serta faktor psikologis yang menjadi ujung tombak untuk menggerakkan hati individu-individu masyarakat untuk berkerja sama mensukseskan program DMIJ, terutama masyarakat yang secara teknis tidak bisa diraih secara mutlak.

\section{Kesimpulan}

Tiga faktor yang mempengaruhi partisipasi masyarakat yaitu faktor teknis, sosiologi, dan psikologi harus disingkronisasikan. Ketiganya harus diperkuat dengan tetap saling terhubung satu dan lainnya.

Pejabat yang berwenang dalam program DMIJ dalam setiap langkahnya menjalankan program DMIJ harus tetap memperhatikan keterkaitan tiga faktor ini. Pejabat berwenang memiliki kekuatan terhadap faktor teknis serta membaca faktor sosiologis masyarakat, namun penajabt berwenang harus turut memfokuskan orientasi akhir kepada faktor psikologis dikarenakan segala upaya melalui faktor teknis dan sosiologis akan berujung kepada psikologis individu masyarakat. Apakah masyarakat denga suka rela, berminta, atau bahkan menolak untuk berpartisipasi.

DMIJ plus terintegrasi sendiri sudah memiliki beberapa program kegiatan untuk mensukseskan DMIJ itu sendiri. Diantaranya diskusi atau sosialisasi langsung dengan masyarakat. Kegiatan-kegiatan yang selama ini dilaksanakan oleh pejabat berwenang diharapkan terus ditingkatkan dengan memperhatikan kesinambungan 3 faktor ini. Terutama faktor psikologi yang selama ini mungkin tidak begitu diperhatikan.

\section{Rekomendasi}

Penulis telah menjelaskan sebelumnya bahwa kegiatan-kegiatan yang telah dilaksanakan untuk program DMIJ harus memperhatikan kesinambungan dan fokus terhadap 3 faktor. Kemudian diharapkan faktor psikologi yang secara data dan fisik tidak begitu terlihat bisa mendapat perhatian lebih, dikarenakan mungkin selama ini faktor ini kurang mendapat tempat.

Berikut hal-hal yang harus diperhatikan dan menjadi fokus pejabat berwenang dalam setiap langkah teknis program DMIJ plus Terintegrasi:
1. Kegiatan teknis harus memperhatikan kondisi sosiologis masyarakat setempat seperti pekerjaan, pendapatan, umur, budaya, dll. Dengan orientasi menemukan apa yang menjadi ciri khas dan profil masyarakat umum setempat sehingga dalam proses sosialisasi dan diskusi serta pengambilan keputusan lainnya bisa mencocokan dengan jati diri masyarakat setempat.

2. Teknis kegiatan harus berorientasi kepada meningkatkan kemauan atau minat masyarakat untuk berpartisipasi dalam program DMIJ.

3. Teknis kegiatan harus berorientasi kepada meningkatkan kepercayaan diri masyarakat unutk yakin bahwa mereka bisa turut andil dalam kemajuan desa mereka

4. Teknis kegiatan harus berorientasi kepada meningkatan rasa percaya masyarakat bahwa mereka dibutuhkan dalam program DMIJ ini.

5. Teknis kegiatan harus berorientasi kepada meyakinkan masyarakat bahwa mereka harus ikut dan ambil bagian dalam program DMIJ

6. Teknis kegiatan harus mengikir kondisikondisi dimana ada masyarakat yang dikucilkan dan merasa tidak dianggap

7. Teknis kegiatan harus berorientasi kepada memberikan penghargaan terhadap partisipasi masyarakat. penghargaan bisa dalam bentuk apapun, baik uang tunai, bantuan peralatan, dll.

\section{Penelitian Lanjutan}

Diharapkan ada penelitian lanjutan untuk lebih meningkatkan performa program DMIJ plus Terintegrasi. Diantaranya adalah:

1. Kajian sosiologis desa-desa di Kabupaten Indragiri Hilir

2. Strategi peningkatan kondisi psikologis masyarakat untuk berpartisipasi dalam program DMIJ

3. Kajian benchmark atau best praktis Negara lain yang telah berhasil melakukan proyek perdesaan

\section{DAFTAR PUSTAKA}

[1] Ife, Jim dan Tesoriero, Frank. 2008. Community Development: Alternatif Pengembangan Masyarakat di Era Globalisasi. Yogyakarta: Penerbit Pustaka Pelajar.

[2] Jalal, Fasli dan Dedi Supriadi, 2001, Reformasi Pendidikan Dalam Konteks Otonomi Daerah, Yogyakarta: Adicita Karya Nusa.

[3] Mikkelsen, Britha. 1999. Metode Penelitian Partisipatoris Dan UpayaUpaya Pemberdayaan: Sebuah Buku 
Pegangan Bagi Para Praktisi Lapangan. Jakarta: Yayasan Obor Indonesia.

[4] Mohtar Mas'oed - Colin MacAndrews, 2008 Perbandingan Sistem Politik. Yogyakarta: . Gadjah Mada University Press

[5] Rush \& Philip Altopff. 1998. Pengantar Sosiologi Politik. Jakarta : Raja Grafindo

[6] Slamet. 2003. Pembangunan Masyarakat Berwawasan Partisipasi. Surakarta: Sebelas Maret University Press.

[7] Soelaiman, Holil. 1980. Partisipasi sosial dalam usaha kesejahteraan sosial. Bandung: Badan Penelitian dan Pengembangan Sosial.

[8] Sunarti. 2003. Partisipasi Masyarakat dalam Pembangunan Perumahan secara Kelompok. Jurnal Tata Loka. Semarang: Planologi UNDIP.

[9] Yulianti, Yoni. 2012. Analisis Partisipasi Masyarakat dalam Pelaksanaan Program Nasional Pemberdayaan Masyaarakat (PNPM) Mandiri Perkotaan. Padang : Universitas Andalas 